\title{
The influence of stochastic and selective forces in the population divergence of female colour polymorphism in damselflies of the genus Ischnura
}

\author{
RA Sánchez-Guillén ${ }^{1}$, B Hansson ${ }^{2}$, M Wellenreuther ${ }^{2}$, EI Svensson ${ }^{2}$ and A Cordero-Rivera ${ }^{1}$ \\ ${ }^{1}$ Departamento de Ecoloxía e Bioloxía Animal, E. U. E. T. Forestal, Universidade de Vigo, Pontevedra, Spain and ${ }^{2}$ Department of Biology, \\ Lund University, Lund, Sweden
}

\begin{abstract}
Disentangling the relative importance and potential interactions of selection and genetic drift in driving phenotypic divergence of species is a classical research topic in population genetics and evolutionary biology. Here, we evaluate the role of stochastic and selective forces on population divergence of a colour polymorphism in seven damselfly species of the genus Ischnura, with a particular focus on $I$. elegans and I. graellsii. Colour-morph frequencies in Spanish I. elegans populations varied greatly, even at a local scale, whereas more similar frequencies were found among populations in eastern Europe. In contrast, I. graellsii and the other five Ischnura species showed little variation in colour-morph frequencies between populations. $F_{\mathrm{ST}}$-outlier analyses revealed that the colour locus deviated strongly from neutral expectations in Spanish populations of $I$.
\end{abstract}

elegans, contrasting the pattern found in eastern European populations, and in I. graellsii, where no such discrepancy between morph divergence and neutral divergence could be detected. This suggests that divergent selection has been operating on the colour locus in Spanish populations of l. elegans, whereas processes such as genetic drift, possibly in combination with other forms of selection (such as negative frequency-dependent selection), appear to have been present in other regions, such as eastern Europe. Overall, the results indicate that both selective and stochastic processes operate on these colour polymorphisms, and suggest that the relative importance of factors varies between geographical regions.

Heredity (2011) 107, 513-522; doi:10.1038/hdy.2011.36; published online 18 May 2011

Keywords: divergent selection; balancing selection; genetic drift; $F_{\mathrm{ST}}$-outlier; colour polymorphism; damselflies

\section{Introduction}

Ever since the start of the 'Modern Synthesis' (Wright, 1931, 1956; Fisher, 1958), the relative influence of different modes of selection and stochastic processes, like genetic drift, in driving phenotypic divergence of species has been a central research question in population genetics and evolutionary biology. In small populations, genetic drift might influence the divergence of adaptive phenotypic traits, particularly during periods of relaxed selection (Orr, 1998; Gray and McKinnon, 2007). Species with heritable colour polymorphisms are suitable model systems to study the interplay between selection and genetic drift in the phenotypic population divergence (Nevo, 1997; Hoffman et al., 2006; Gray and McKinnon, 2007; Svensson et al., 2009). Several different processes can affect the frequencies of colour morphs in populations, including genetic drift (Oxford, 2005; Gray and McKinnon, 2007), negative frequency-dependent selection (Svensson et al., 2005; Abbott et al., 2008) and directional selection in spatially and temporally hetero-

Correspondence: $\operatorname{Dr}$ RA Sánchez-Guillén, Departamento de Ecoloxía e Bioloxía Animal, E. U. E. T. Forestal, Universidade de Vigo, Pontevedra, 36005 Spain.

E-mail: rguillen@uvigo.es

Received 21 July 2010; revised 31 March 2011; accepted 4 April 2011; published online 18 May 2011 geneous habitats (Gray and McKinnon, 2007). If the balancing force of negative frequency-dependent selection is predominant, then populations are expected to reach similar morph frequencies at equilibrium, compared with a situation where genetic drift or diversifying selection is the dominant force (Abbott et al., 2008; Andrés et al., 2000, 2002). In contrast, if divergent selection operates and favours different colour morphs in heterogeneous environments, then the degree of population divergence in morph frequencies is expected to be higher than by drift alone (Wong et al., 2003).

Female colour polymorphism is common in odonates (dragonflies and damselflies), and more than 130 polymorphic odonate species have been described so far (Fincke et al., 2005). However, the degree of polymorphism within odonate families varies markedly. For example, $65 \%$ of the polymorphic species in the European fauna belong to the family Coenagrionidae (Cordero and Andrés, 1996), and many of these colour morphs are known to co-occur within the same local populations in the wild. In Coenagrionidae, morphs typically consist of one androchrome (male-mimicking) morph, and one or several discrete female-specific morphs, often called gynochromes (sensu Hilton, 1987).

Several adaptive hypotheses, based on sexual conflict over mating opportunities, have been proposed to explain the maintenance of colour polymorphisms in odonates. These hypotheses include either frequency- or 
density-dependent mechanisms, or both. The decisive factor under density-dependent selection is the number of females of each morph, or the number of males. Hinnekint (1987) proposed that males prefer to mate with the gynochrome females at low densities, and that the androchrome females are then at a disadvantage, because they risk to remain unmated. Conversely, at high densities, gynochrome females would be at a disadvantage due to the fitness costs resulting from high male mating harassment. The polymorphism is thus supposed to be maintained by cyclic fluctuations in population density (Hinnekint and Dumont, 1989; Cordero, 1992). On the other hand, under frequency-dependent selection, it is the female morph frequencies that are important (Robertson, 1985; Sherratt, 2001; Fincke, 2004; Svensson et al., 2005). As a rare female morph becomes more common in the population, males are expected to switch their attention to those morphs in a frequencydependent manner, which will cause apostatic selection and a fitness disadvantage of the locally most frequent morph (Fincke, 2004; Svensson et al., 2005; Gosden and Svensson, 2009). However, because androchrome females mimic males, males should behave indiscriminately when most females are androchromes, as they would otherwise lose mating opportunities (Robertson, 1985; Sherratt, 2001; Cordero-Rivera and Sánchez-Guillén, 2007). These rapid frequency-dependent switches in female mating harassment are thought to be facilitated by plastic mate preferences (Miller and Fincke, 1999; Fincke, 2004).

In the last decade, different approaches have been utilised to examine the nature of selection operating on such heritable polymorphisms in the wild. Gillespie and Oxford (1998) proposed that insights into the relative importance of divergent and negative frequency-dependent selection can be obtained by contrasting the degree of genetic differentiation at a specific locus, in this case the colour-morph locus, to the degree of differentiation at neutral markers. Several recent studies on damselfly species have utilised this approach, but they have reached different conclusions regarding the relative importance of selection and drift. In both Ischnura graellsii (Andrés et al., 2000) and Ceriagrion tenellum (Andrés et al., 2002), the colour-morph locus divergence was lower, compared with the neutral divergence between populations, suggesting that negative frequency-dependent selection towards a common equilibrium does constrain population divergence. In contrast, a study by Wong et al. (2003) on Nehalennia irene found evidence for more pronounced population divergence at the morph locus than at neutral loci, suggesting that divergent selection has caused the pronounced differences in morph frequencies in local populations of this species. Finally, Abbott et al. (2008) studied populations of Ischnura elegans and found that some sort of balancing selection on the colour-morph locus operated in some years, whereas divergent selection was predominant in other years.

I. graellsii and I. elegans are two closely related species (Carchini et al., 1994) with very similar morphology (Monetti et al., 2002). In comparison, I. graellsii shows a limited distribution on the Iberian Peninsula and adjacent areas of northern Africa, whereas I. elegans has a wider distribution, encompassing both Europe and western Asia (Dijkstra and Lewington, 2006). As a result of their ecological and morphological similarities, the two species hybridise where their distributional ranges overlap (Monetti et al., 2002; Sánchez-Guillén et al., 2005). In I. graellsii, the female colour-morph frequencies are almost uniform among populations, with the infuscans (gynochrome) morph being the majority morph (Andrés et al., 2000; Sánchez-Guillén et al., 2005). In contrast, the female colour-morph frequencies in I. elegans vary substantially among populations, at both regional and continental scales (Gosden, 2008; Hammers and Van Gossum, 2008; Cordero-Rivera and Sánchez-Guillén 2007). Hammers and Van Gossum (2008) and Gosden (2008) studied the colour-morph frequency of European populations of I. elegans on a small and large scale, respectively. Although both studies found a geographic gradient in androchrome frequencies, Hammers and Van Gossum (2008) found an increase towards the north and east of the Netherlands and Belgium (Hammers and Van Gossum, 2008), whereas Gosden (2008) found a highly significant large-scale geographic cline towards the north. It was suggested that populations near the range limit might have had less time to reach an equilibrium of morph frequencies that would be expected under negative frequency-dependent selection, compared with those at the centre and in the southern part of the distributional range (Gosden, 2008). In addition, it has been proposed that morph frequencies in southern European populations of I. elegans are affected by a combination of various types of selection and genetic drift due to small population sizes, and/or recent founder events, and potentially also through hybridisation with I. graellsii (Gosden, 2008).

Here, we evaluate whether and how different modes of selection operate on the colour polymorphism in the sister species I. elegans and I. graellsii. We follow the approach suggested by (Kay et al. (2007) and compare morph-frequency divergence in different parts of the distributional range of I. elegans. We further review the literature on colour-morph frequencies in these two and five other species of the genus Ischnura to evaluate if colour-morph frequencies are generally stable among populations, and if the androchrome morph can also reach high frequencies in species other than I. elegans. We also use the $F_{\mathrm{ST}}$-outlier procedure described by Beaumont and Nichols (1996), as modified by Excoffier et al. (2009), to generate null distributions of neutral $F_{\mathrm{ST}}$ values at different levels of variability and to evaluate signs of different types of selection at the colour locus.

\section{Materials and methods}

\section{Colour-morph frequencies}

To evaluate colour-morph frequency patterns in Ischnura species, we used colour-morph frequencies of populations from the literature, and we also collected data from additional populations (Tables 1 and 2). We analysed female morph frequencies from the literature in seven I. graellsii populations from Iberia (Andrés et al., 2000; Sánchez-Guillén et al., 2005), five I. elegans populations from eastern Europe (Gosden, 2008), four I. senegalensis populations from Japan (Takahashi and Watanable, 2009), four I. fluviatilis populations from Uruguay (Mckee et al., 2005), four I. damula (Johnson, 1964), three I. ramburii (Robertson, 1985; Sirot et al., 2003) and two 
Table 1 Frequencies of female colour morphs in natural populations of Ischnura elegans and I. graellsii

\begin{tabular}{|c|c|c|c|c|c|c|c|c|}
\hline \multirow[t]{2}{*}{ Species } & \multirow[t]{2}{*}{ Locality } & \multirow[t]{2}{*}{ Country } & \multirow[t]{2}{*}{ Date } & \multicolumn{4}{|c|}{ Observed frequencies } & \multirow[t]{2}{*}{ Source } \\
\hline & & & & $N$ & $A$ & $I$ & $O$ & \\
\hline I. elegans & Suchoi Limon* & Ukraine & Мay-2006 & 39 & 33.3 & 66.7 & 0.0 & Gosden (2008) \\
\hline I. elegans & Enmakov Island* & Ukraine & May-2006 & 64 & 31.3 & 68.8 & 0.0 & Gosden (2008) \\
\hline I. elegans & Lublin-Zemborzyce* & Poland & Jul-2007 & 45 & 22.2 & 71.11 & 6.7 & Gosden (2008) \\
\hline I. elegans & Zwięczyca Reszów* & Poland & Jul-2007 & 34 & 23.5 & 76.5 & 0.0 & Gosden (2008) \\
\hline I. elegans & Breznica* & Poland & Jul-2007 & 39 & 25.6 & 66.7 & 7.7 & Gosden (2008) \\
\hline I. elegans & Arreo* & Spain & Jul-2008 & 30 & 6.3 & 68.8 & 25.0 & This study \\
\hline I. elegans & Alfaro* & Spain & Jul-2007 & 33 & 69.7 & 27.3 & 3.0 & This study \\
\hline I. elegans & Baldajo* & Spain & Aug-2008 & 34 & 29.4 & 58.8 & 11.8 & This study \\
\hline I. elegans & Almoquera & Spain & Aug-2008 & 28 & 42.9 & 42.9 & 14.3 & This study \\
\hline I. elegans & Europa* $^{*}$ & Spain & Jul-2008 & 30 & 16.7 & 6.7 & 76.7 & This study \\
\hline I. elegans & Amposta* & Spain & Jul-2008 & 30 & 3.3 & 33.3 & 63.3 & This study \\
\hline I. elegans & Marjal del Moro* & Spain & Sept-2008 & 25 & 36.0 & 20.0 & 44.0 & This study \\
\hline I. elegans & Caixanet & Spain & Sept-2009 & 27 & 25.9 & 25.9 & 48.1 & This study \\
\hline I. elegans & Doniños* & Spain & Jun-2007 & 40 & 20.0 & 75.0 & 5.0 & This study \\
\hline I. elegans & Louro* & Spain & Agu-2007 & 63 & 74.6 & 20.6 & 4.8 & This study \\
\hline I. elegans & Foz & Spain & Jun-2007 & 20 & 25.0 & 75.0 & 0.0 & This study \\
\hline I. graellsii & Ribeira de Cobres* & Portugal & Apr-2003 & 48 & 18.8 & 72.9 & 8.3 & Sánchez-Guillén et al. (2005) \\
\hline I. graellsii & Jaraiz de la Vera & Spain & Jun-2007 & 67 & 13.5 & 64.9 & 21.6 & This study \\
\hline I. graellsii & Doñana & Spain & Jun-2003 & 77 & 10.4 & 76.6 & 13.0 & Sánchez-Guillén et al. (2005) \\
\hline I. graellsii & La Cañas & Spain & Jul-2007 & 23 & 17.4 & 69.6 & 13.0 & This study \\
\hline I. graellsii & Alfaro & Spain & Jul-2007 & 23 & 13.0 & 60.9 & 26.1 & This study \\
\hline I. graellsii & Troi & Spain & Jul-2008 & 54 & 14.8 & 72.2 & 13.0 & This study \\
\hline I. graellsii & Córdoba* & Spain & Sept-2008 & 35 & 11.4 & 77.1 & 11.4 & This study \\
\hline I. graellsii & Puente de los Arenales & Spain & Sept-2008 & 33 & 3.0 & 78.8 & 18.2 & This study \\
\hline I. graellsii & Castelo & Spain & Jun-1999 & 42 & 11.9 & 76.2 & 11.9 & Andrés et al. (2000) \\
\hline I. graellsii & Corrubedo & Spain & Jun-1999 & 28 & 21.4 & 60.7 & 17.9 & Andrés et al. (2000) \\
\hline I. graellsii & Campus* & Spain & Jun-1999 & 68 & 1.5 & 89.7 & 8.8 & Andrés et al. (2000) \\
\hline I. graellsii & O Rosal & Spain & Jun-1999 & 68 & 8.8 & 85.3 & 5.9 & Andrés et al. (2000) \\
\hline I. graellsii & A Lanzada & Spain & Jun-1999 & 75 & 14.7 & 76.0 & 9.3 & Andrés et al. (2000) \\
\hline I. graellsii & Saidia* & Morocco & Jun-2009 & 29 & 10.3 & 89.7 & 0.0 & This study \\
\hline
\end{tabular}

The number of mature female examined in each locality is indicated (N). A: androchrome, I: infuscans and O: infuscans-obsoleta (I. elegans) or aurantiaca (I. graellsii). Indicated populations $(*)$ were used in the genetic analysis.

Table 2 Frequencies of female morphs in natural populations of five dimorphic Ischnura species: I. senegalensis, I. fluviatilis, I. damula, I. ramburii and I. denticollis

\begin{tabular}{|c|c|c|c|c|c|c|}
\hline \multirow[t]{2}{*}{ Species } & \multirow[t]{2}{*}{ Country } & \multirow[t]{2}{*}{ Date } & \multicolumn{3}{|c|}{ Observed frequencies } & \multirow[t]{2}{*}{ Source } \\
\hline & & & $N$ & $A$ & $G$ & \\
\hline I. senegalensis & Japan & May-2007 & 37 & 21.6 & 78.4 & Takahashi and Watanable (2009) \\
\hline I. senegalensis & Japan & Jun-2007 & 42 & 35.7 & 64.3 & Takahashi and Watanable (2009) \\
\hline I. senegalensis & Japan & Jun-2006 & 42 & 26.2 & 73.8 & Takahashi and Watanable (2009) \\
\hline I. senegalensis & Japan & Nov-2005 & $? ?$ & 22.9 & 77.1 & Takahashi and Watanable (2009) \\
\hline I. fluviatilis & Uruguay & Dec-2002 & 194 & 7.7 & 92.3 & Mckee et al. (2005) \\
\hline I. fluviatilis & Uruguay & Jan-2003 & 141 & 7.8 & 92.2 & Mckee et al. (2005) \\
\hline I. fluviatilis & Uruguay & Feb-2003 & 72 & 8.3 & 91.7 & Mckee et al. (2005) \\
\hline I. fluviatilis & Uruguay & Jan-2003 & 66 & 4.5 & 95.5 & Mckee et al.(2005) \\
\hline I. damula & North America & Apr-1963 & 72 & 11.1 & 88.9 & Johnson (1964) \\
\hline I. damula & North America & May-1963 & 60 & 11.7 & 88.3 & Johnson (1964) \\
\hline I. damula & North America & Dec-1963 & 43 & 16.3 & 83.7 & Johnson (1964) \\
\hline I. damula & North America & Nov-1962 & 51 & 15.7 & 84.3 & Johnson (1964) \\
\hline I. ramburii & North America & May-1983 & 90 & 31.1 & 68.9 & Robertson (1985) \\
\hline I. ramburii & North America & May-1983 & 44 & 25.0 & 75.0 & Robertson (1985) \\
\hline I. ramburii & North America & May-1998 & 94 & 36.2 & 63.8 & Sirot et al. (2003) \\
\hline I. denticollis & North America & ?? & 94 & 24.0 & 76.0 & Fincke et al. (2005) \\
\hline I. denticollis & North America & ??-1991 & 450 & 51.0 & 49.0 & Córdoba-Aguilar (1993) \\
\hline
\end{tabular}

The number of mature female examined in each locality is indicated $(\mathrm{N})$. A: androchrome, G: gynochrome.

I. denticollis (Fincke et al., 2005; Córdoba-Aguilar, 1993) populations from north America (Tables 1 and 2).

In addition, we estimated female colour-morph frequencies in six populations of I. graellsii from Iberia and northern Africa and in 12 populations of I. elegans from Spain (Table 1). These populations were visited during three consecutive years (2007, 2008 and 2009) between April and September on sunny days. Colour-morph frequencies were estimated by counting the number of each morph present and then dividing this by the total number of females in the population (ranging between 20 and 75 females, depending on the density of the 
population). The smaller sample sizes are for populations with very low densities, and it should be kept in mind that uncertainty in the estimations of the population frequency will be induced by sampling errors (Kay et al., 2007). The sampling was carried out with entomological nets, and only single, solitary and mature females, which were not in tandem or mating, were counted. After the phenotype of the females was scored, each female was marked with a black dot on the wing, to avoid re-counting the same individual.

\section{Genetic differentiation of populations of I. elegans and I. graellsii}

For the genetic study, we collected I. elegans individuals from eight populations from Spain and five populations from eastern Europe. For I. graellsii, we selected three Iberian populations and one population from northern Africa, all of which were outside the distributional range of $I$. elegans, to avoid confounding the results due to hybridisation (Sánchez-Guillén et al., 2005) (Table 1). In each population, 20 males were collected for molecular analysis and preserved in ethanol. DNA was extracted with a standard phenol-chloroform protocol (Sambrook et al., 1989). Alleles at six microsatellite loci (I-002, I-015, I-041, I-053, I-095 and I-134) were amplified in I. elegans and at five loci in $I$. graellsii (I-002, I-015, I-041, I-053, I-095) by PCR using the protocol described by (Wellenreuther et al. (2010). These loci did not deviate from Hardy-Weinberg expectations and linkage equilibrium, and showed no evidence for the presence of null alleles in $I$. elegans, the species in which the microsatellites were characterised (Wellenreuther et al., 2010). The PCR products were separated and alleles were detected using an ABI PRISM 3730 capillary sequencer (Applied Biosystems, Stockholm, Sweden). GeneMapper 3.0 (Applied Biosystems) was used to determine the genotypes of the individuals for the neutral loci. Basic population statistics for the microsatellites were assessed in terms of expected heterozygosity $\left(\mathrm{H}_{\mathrm{E}}\right)$, observed heterozygosity $\left(\mathrm{H}_{\mathrm{O}}\right)$, number of alleles and allelic richness, using the program FSTAT version 2.9.3.2 (Goudet, 1995, 2001).

The inheritance system for female colouration has been reported for both species (Cordero, 1990; SánchezGuillén et al., 2005), and shows that the morphs are controlled by a single autosomal locus with three alleles that are under a hierarchical dominance: androchrome allele $\left(\mathrm{A}_{\text {allele }}\right)$ is dominant over both the infuscans $\left(\mathrm{I}_{\text {allele }}\right)$ and the infuscans-obsoleta $\left(\mathrm{O}_{\text {allele }}\right)$ alleles, and $\mathrm{I}_{\text {allele }}$ is dominant over $\mathrm{O}_{\text {allele }}$ (that is, $\mathrm{A}_{\text {allele }}>\mathrm{I}_{\text {allele }}>\mathrm{O}_{\text {allele }}$ ). The androchrome morph has three possible genotypes $\left(\mathrm{A}_{\text {allele }} \mathrm{A}_{\text {allele, }} \mathrm{A}_{\text {allele }} \mathrm{I}_{\text {allele, }} \mathrm{A}_{\text {allele }} \mathrm{O}_{\text {allele }}\right)$, the gynochrome morph infuscans represents two possible genotypes $\left(\mathrm{I}_{\text {allele }} \mathrm{I}_{\text {allele, }} \mathrm{I}_{\text {allele }} \mathrm{O}_{\text {allele }}\right)$ and the other gynochrome morph (infuscans-obsoleta in I. elegans and aurantiaca in I. graellsii) represents a single genotype $\left(\mathrm{O}_{\text {allele }} \mathrm{O}_{\text {allele }}\right)$ (Cordero, 1990; Sánchez-Guillén et al., 2005). Using our knowledge about the genetic basis of this colour polymorphism, colour-morph frequencies were used to estimate allelic frequencies, using the maximum probability estimates of Hedrick (1985) along with the phenotypic frequencies, while assuming Hardy-Weinberg equilibrium within populations. Lastly, allele frequencies were used to estimate genotypic frequencies, starting from which was considered the genetic differentiation degree by the program FSTAT Ver. 2.9.3.2 (Goudet, 1995).
For those populations for which we did not find any infuscans-obsoleta (or aurantiaca) specimens (see Table 1), presumably due to a combination of small-population sample sizes and low frequencies of the $\mathrm{O}_{\text {allele, we }}$ conducted the analyses assuming (i) that the $\mathrm{O}_{\text {allele }}$ was indeed absent (that is, $\mathrm{O}_{\text {allele }}$ had a frequency of $0 \%$ ), and (ii) that the $\mathrm{O}_{\text {allele }}$ was present at low frequencies (5 and $10 \%$, respectively). Calculations of the frequencies of the $\mathrm{A}$ and I alleles were then done for each of these populations using observed genotype frequencies and each of the assumed $\mathrm{O}_{\text {allele }}$ frequencies. The level of heterozygosity $\left(\mathrm{H}_{\mathrm{E}}\right)$ and genetic differentiation among populations $\left(F_{\mathrm{ST}}\right)$ were calculated according to Weir and Cockerham, (1984) with the program FSTAT V. 2.9.3.2 (Goudet, 1995).

We compared the degrees of differentiation (the $F_{\mathrm{ST}}$ value) at neutral loci and at the colour locus using the $F_{\text {ST-outlier procedure described by Beaumont and }}$ Nichols (1996) and modified by Excoffier et al. (2009). Expected distributions of $F_{\mathrm{ST}}$ values at different degrees of heterozygosity $\left(\mathrm{H}_{\mathrm{E}}\right)$ under neutral conditions were obtained from coalescent simulations using the microsatellite data and hierarchical island models implemented in Arlequin 3.5 (Excoffier et al., 2009; http:/ / anthro.unige.ch/software/arlequin/). These models were used to evaluate whether the colour locus acted as an $F_{\mathrm{ST}}$ outlier in I. elegans population from Spain and eastern Europe, and in the I. graellsii populations. In the hierarchical island models, we defined groups according to results from population structure analyses (SánchezGuillén et al., under review) in the program STRUCTURE (version 2.2.3, Pritchard et al., 2000): Spanish I. elegans were clustered into three groups (populations: 1, 2-5, 68; Table 3), the eastern European populations into two groups (populations: 9-11, 12-13; Table 3), and I. graellsii into three groups (populations: 14, 15-16, 17; Table 3).

We also tested for a correlation between the $F_{\mathrm{ST}}$ values of the colour morphs and the microsatellite loci in both I. elegans and I. graellsii. The degree of correlation can inform us about the importance of genetic drift and selection in maintaining colour-morph frequencies ( $\mathrm{Ru}-$ nemark et al., 2010). A strong correlation would suggest that the colour-morph frequency in local populations is largely affected by genetic drift, whereas a weak correlation would be indicative of selection. A moderate correlation would indicate a combination between drift genetic and selection (Runemark et al., 2010).

\section{Results}

\section{Colour-morph frequencies}

I. graellsii showed similar colour-morph frequencies among populations (Iberia and northern Africa), with the infuscans morph being always the most predominant morph (frequency range: 60-90\%; Table 1) however, we found a marginal but significant difference in colourmorph frequencies among populations $\left(\chi^{2}=40.09\right.$, d.f. $=26, P=0.038$; Figure 1).

In contrast, the colour-morph frequencies in the Spanish I. elegans populations varied widely and highly significantly among populations $\left(\chi^{2}=230.16\right.$, d.f. $=20$, $P<0.0001 ;$ Figure 1). The infuscans-obsoleta morph was the most common morph in the eastern part of Spain 
Table 3 Genetic variation at microsatellite loci for each population of I. elegans and I. graellsii

\begin{tabular}{|c|c|c|c|c|c|c|c|}
\hline Species & Population & Region & $N$ & $H_{O}$ & $H_{E}$ & $A$ & $K$ \\
\hline I. elegans & 1. Doniños & North-West Spain & 20 & 0.711 & 0.700 & 6.8 & 6.6 \\
\hline I. elegans & 2. Louro & North-West Spain & 15 & 0.712 & 0.729 & 5.3 & 5.8 \\
\hline I. elegans & 3. Arreo & North Spain & 15 & 0.631 & 0.761 & 8.3 & 7.8 \\
\hline I. elegans & 4. Baldajo & Central Spain & 17 & 0.603 & 0.795 & 8.0 & 7.7 \\
\hline I. elegans & 5. Alfaro & Central Spain & 20 & 0.663 & 0.758 & 8.3 & 7.0 \\
\hline I. elegans & 6. Europa & North-East Spain & 18 & 0.671 & 0.787 & 8.0 & 7.1 \\
\hline I. elegans & 7. Amposta & East Spain & 20 & 0.691 & 0.770 & 8.5 & 7.2 \\
\hline I. elegans & 8. Marjal del Moro & East Spain & 20 & 0.671 & 0.751 & 7.3 & 5.8 \\
\hline I. elegans & 9. Breznica & South Poland & 18 & 0.712 & 0.796 & 7.8 & 6.7 \\
\hline I. elegans & 10. Zwięczyca Reszów & South Poland & 11 & 0.668 & 0.827 & 8.7 & 7.3 \\
\hline I. elegans & 11. Lublin-Zemborzyce & South Poland & 14 & 0.751 & 0.797 & 10.0 & 8.1 \\
\hline I. elegans & 12. Suchoi Limon & East Ukraine & 20 & 0.719 & 0.791 & 7.5 & 6.5 \\
\hline I. elegans & 13. Enmakov Island & East Ukraine & 15 & 0.713 & 0.766 & 8.2 & 6.8 \\
\hline I. graellsii & 14. Campus & North-West Spain & 17 & 0.485 & 0.694 & 6.2 & 3.2 \\
\hline I. graellsii & 15. Córdoba & South Spain & 20 & 0.647 & 0.653 & 7.2 & 3.5 \\
\hline I. graellsii & 16. Ribeira de Cobres & South Portugal & 14 & 0.684 & 0.719 & 6.2 & 3.7 \\
\hline I. graellsii & 17. Sä̈dia & North Morocco & 13 & 0.490 & 0.677 & 5.0 & 3.1 \\
\hline
\end{tabular}

Number of genotyped individuals $(\mathrm{N})$, observed $\left(\mathrm{H}_{\mathrm{O}}\right)$ and expected heterozygosity $\left(\mathrm{H}_{\mathrm{E}}\right)$, average number of alleles $(\mathrm{A})$ and allelic richness $(\mathrm{K})$ at six loci in I. elegans and five loci in I. graellsii are shown.

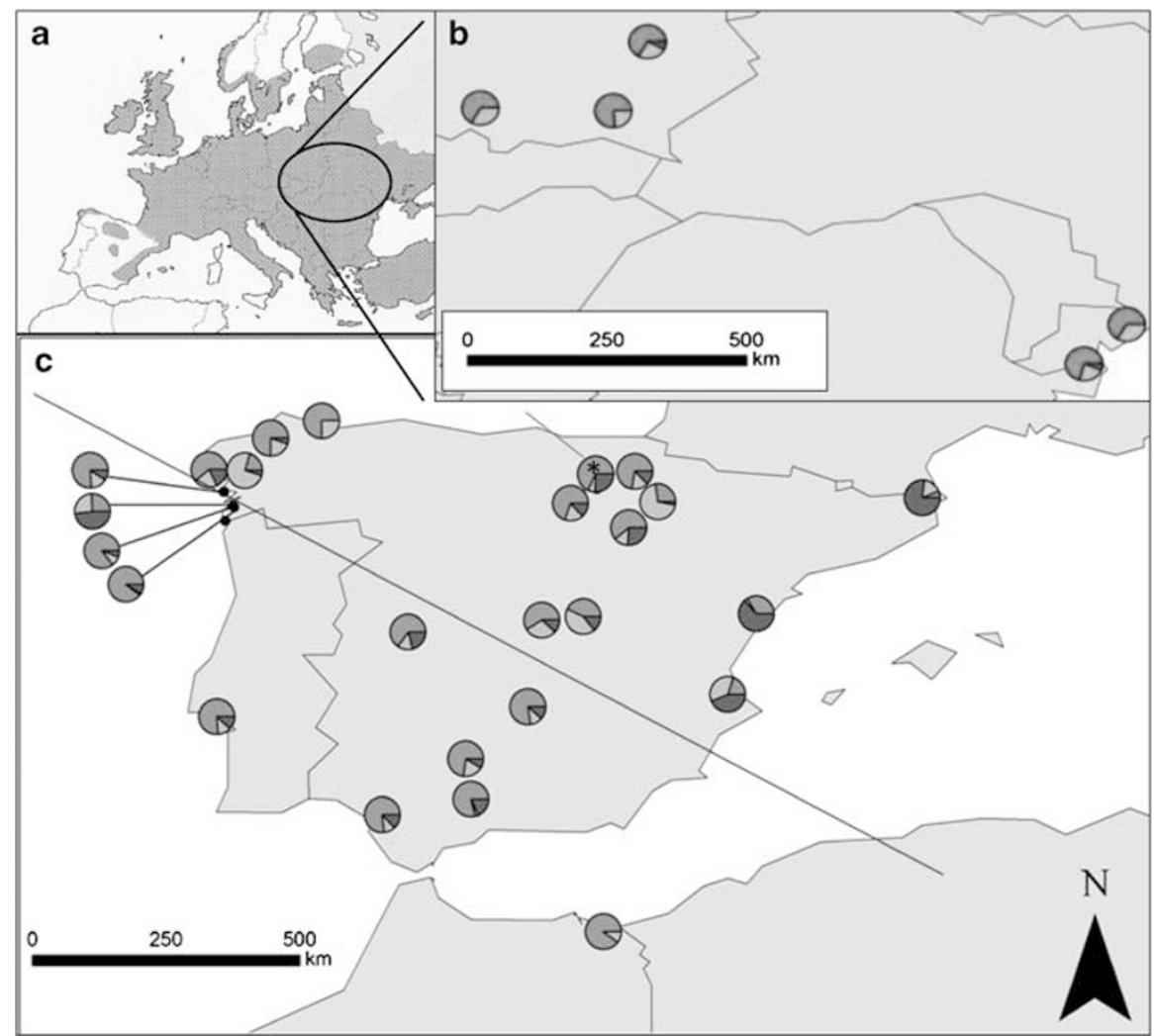

Figure 1 Female morph frequencies (\%) in populations of I. elegans and I. graellsii in Europe. The figure shows the range of I. elegans (map a Dijkstra and Lewington, 2006), and the frequencies of the three female colour morphs, namely the androchrome (gray), infuscans (clear gray) and infuscans-obsoleta morph (black) at each population. The frequencies of the eastern European populations of I. elegans in the Ukraine and in Poland are shown in map $\mathbf{b}$ and of Iberian populations of I. elegans and I. graellsii in map $\mathbf{c}$. The line across Iberia indicates the rough distribution of I. elegans and I. graellsii, with I. elegans being most frequent above the line and I. graellsii below the line. For details of each population, see Table 1. A full color version of this figure is available at the Heredity journal online.

(Europe, Amposta, Barranco de Caixanet and Marjal del Moro, Figure 1), with frequencies between 44-77\%. However, in central (Arreo, Las Cañas, Baldajo and Almoquera) and north-western (Doniños, Louro and Foz) Spain, either the androchrome or the infuscans morph dominated, whereas the infuscans-obsoleta was rare or even absent (Table 1, Figure 1). The colour-morph frequencies were comparably more stable in the eastern European populations of I. elegans $\left(\chi^{2}=12.39\right.$, d.f. $=8$, $P=0.137$; Figure 1), where the infuscans morph dominated (range 67-77\%; Table 1). I. elegans populations in Ukraine were characterised by a complete absence of 
infuscans-obsoleta morphs, and in Poland the infuscansobsoleta morph was only found in one of the three populations (Zwięczyca Reszów; Table 1).

In the case of the additional five dimorphic species in the Ischnura genus that were investigated (using data from the literature), four showed similar frequencies among populations (Table 2), with the gynochrome morph dominating (I. senegalensis: $\chi^{2}=2.48$, d.f. $=3, P=0.478$; I. fluviatilis: $\chi^{2}=0.94$, d.f. $=3, P=0.816 ;$ I. damula: $\chi^{2}=1.026$, d.f. $=3, \quad P=0.795 ; \quad$ I. ramburii: $\chi^{2}=1.41$, d.f. $=2, P=0.492)$. In $I$. denticollis, where we compared only two populations, we found a highly significant difference in the colour-morph frequencies $\left(\chi^{2}=22.18\right.$, d.f. $=1, P<0.0001)$, with the gynochrome morph dominating in one population, whereas the morphs showed very similar frequencies in the other population (Table 2).

\section{Genetic differentiation of populations of $I$. elegans and I. graellsii}

The degree of genetic variation at the microsatellite loci was very high and similar between different I. elegans populations (Table 3 ) in terms of observed and expected heterozygosity (0.60-0.75 and 0.70-0.83, respectively), average number of alleles (5.3-10.0) and allelic richness (5.8-8.1) (Table 3). In contrast, I. graellsii populations showed moderate amounts of genetic variation (observed heterozygosity: 0.49-0.68; expected heterozygosity: $0.65-0.72$; average number of alleles: 5.0-7.2; allelic richness 3.1-3.7; Table 3).

In $I$. elegans, the $F_{\mathrm{ST}}$ values between population pairs for the six microsatellite loci ranged between -0.002 and 0.145 , and for the colour locus they ranged between -0.006 and 0.529 , respectively (Table 4). In I. graellsii, we found an overall lower differentiation between populations, and the $F_{\mathrm{ST}}$ values between population pairs for five microsatellites and the colour locus ranged from -0.018 to 0.068 , and from -0.010 to 0.259 , respectively (Table 5).

Analysing the full sample of $I$. elegans populations (Spain and eastern Europe), the results from the $F_{\text {ST }}$-outlier analyses (using hierarchical island models implemented in Arlequin 3.5) showed that the colour locus $\left(F_{\mathrm{ST}}=0.271\right)$ behaved as an outlier with an $F_{\mathrm{ST}}$ value larger than the generated null distribution of neutral $F_{\mathrm{ST}}$ values (Figure 2a). In addition, when we assumed low frequencies of the $\mathrm{O}_{\text {allele }}$ in populations where we did not observe any infuscans-obsoleta individuals, the $F_{\mathrm{ST}}$ values of the colour locus $\left(F_{\mathrm{ST}}=0.243\right.$ and 0.223 , assuming frequencies of the $\mathrm{O}_{\text {allele }}$ of 5 and $10 \%$, respectively) fell outside the expected neutral $F_{\mathrm{ST}}$-distribution (Figure $2 \mathrm{a}$ ).

Similar results were found when we investigated only the Spanish populations of I. elegans. The analysis showed again that the colour locus was a clear $F_{\mathrm{ST}}$-outlier $\left(F_{\mathrm{ST}}=0.231\right.$; Figure $\left.3 b\right)$.

In contrast, in I. elegans populations from eastern Europe, the colour locus $\left(F_{\mathrm{ST}}=0.084\right)$ did not deviate strongly from the neutral expectations, in particular, not when we assumed low frequencies of the $\mathrm{O}_{\text {allele }}(5$ and $10 \%$, respectively) in the populations where we did not observe any infuscans-obsoleta individuals $\left(F_{\mathrm{ST}}=0.046\right.$ and 0.025, respectively; Figure 2c).

In I. graellsii populations, the $F_{\mathrm{ST}}$ value for the colour locus was 0.086, and if we assumed low frequencies for the $\mathrm{O}_{\text {allele }}$ ( 5 and $10 \%$, respectively) in the populations where we did not observe any aurantiaca individuals, the obtained value for the colour $F_{\mathrm{ST}}$ was 0.064 and 0.040 , respectively. Unlike for $I$. elegans, the $F_{\mathrm{ST}}$-outlier analysis showed that the $F_{\mathrm{ST}}$ values of the colour locus did not deviate from the neutral expectations (Figure 2d).

The degree of differentiation at the set of microsatellite loci between all $I$. elegans populations $(\mathrm{N}=13)$ did not correlate significantly with the degree of differentiation at the colour locus $\left(\mathrm{F}_{1,74}=0.135, P=0.24 ; r^{2}=0.018\right.$; Figure 3). In I. graellsii, the correlation between differentiation at the neutral loci and the colour locus for the four populations was slightly higher than in I. elegans; however, this correlation was also far from being significant $\left(F_{1,5}=0.524, P=0.28 ; r^{2}=0.27\right.$; Figure 3$)$.

Table 5 Degree of differentiation $\left(\mathrm{F}_{\mathrm{ST}}\right)$ between I. graellsii populations for five neutral loci (above diagonal) and for the colour locus (below diagonal)

\begin{tabular}{lrrrr}
\hline & pоp 1 & рор 2 & рор 3 & \multicolumn{1}{c}{ рор 4 } \\
\hline 1. Córdoba & & 0.018 & 0.003 & 0.065 \\
2. Ribeira de Cobres & -0.010 & & 0.017 & 0.068 \\
3. Campus & 0.001 & 0.007 & & -0.018 \\
4. Saïdia & 0.259 & 0.217 & 0.188 & \\
\hline
\end{tabular}

Table 4 Degree of differentiation $\left(\mathrm{F}_{\mathrm{ST}}\right.$ ) between I. elegans populations for six neutral loci (above diagonal) and for the colour locus (below diagonal)

Spanish populations

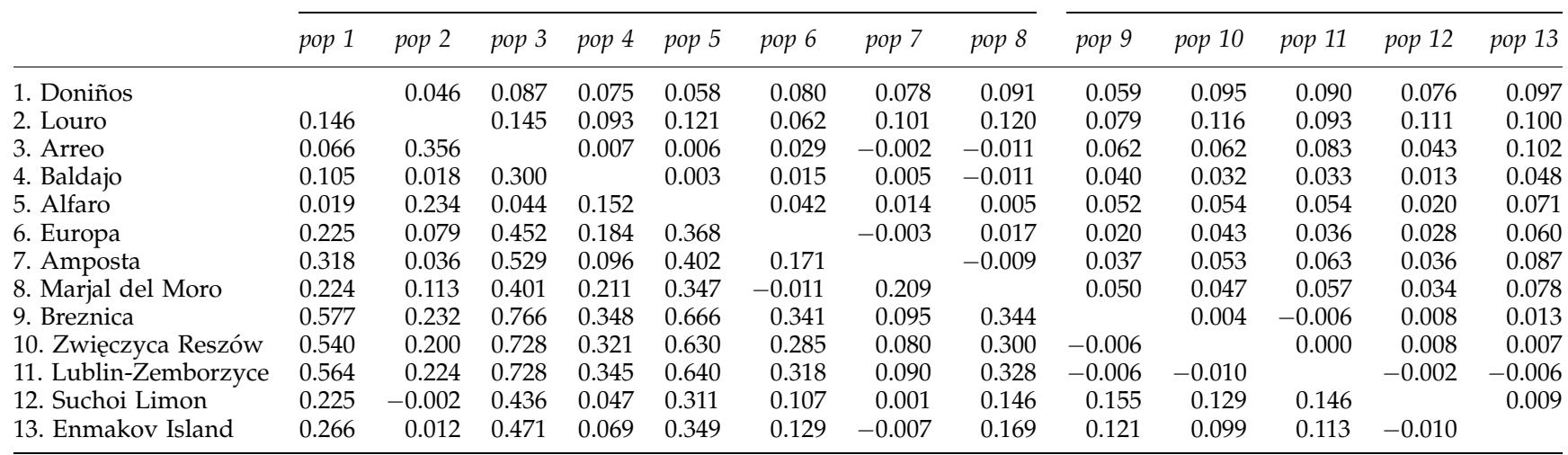


a

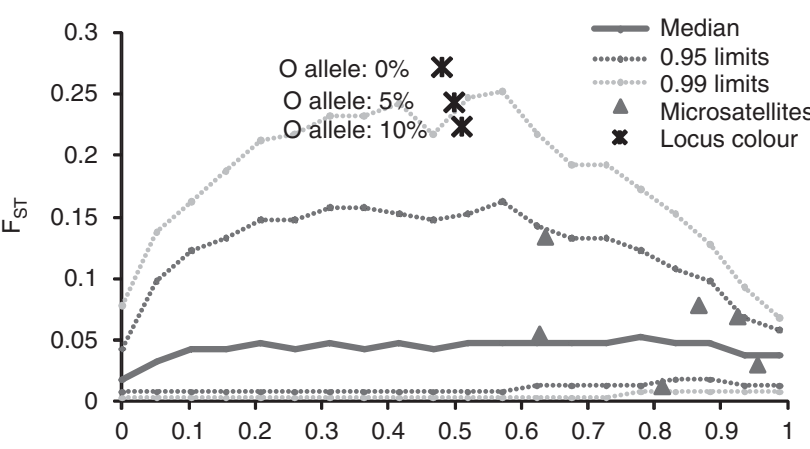

b

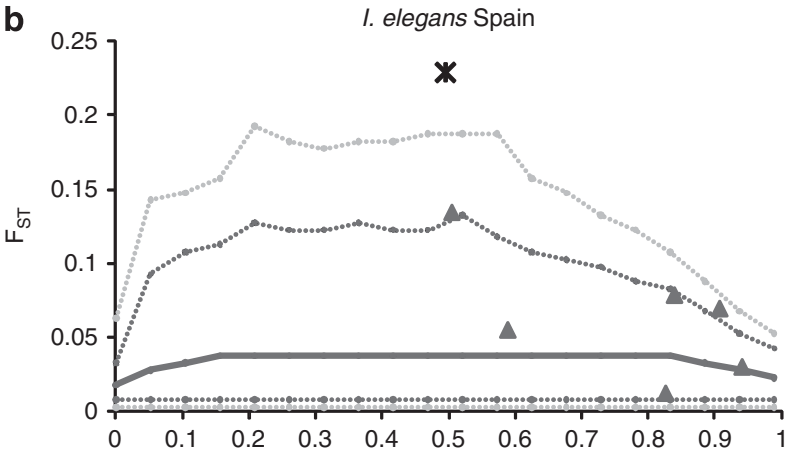

c
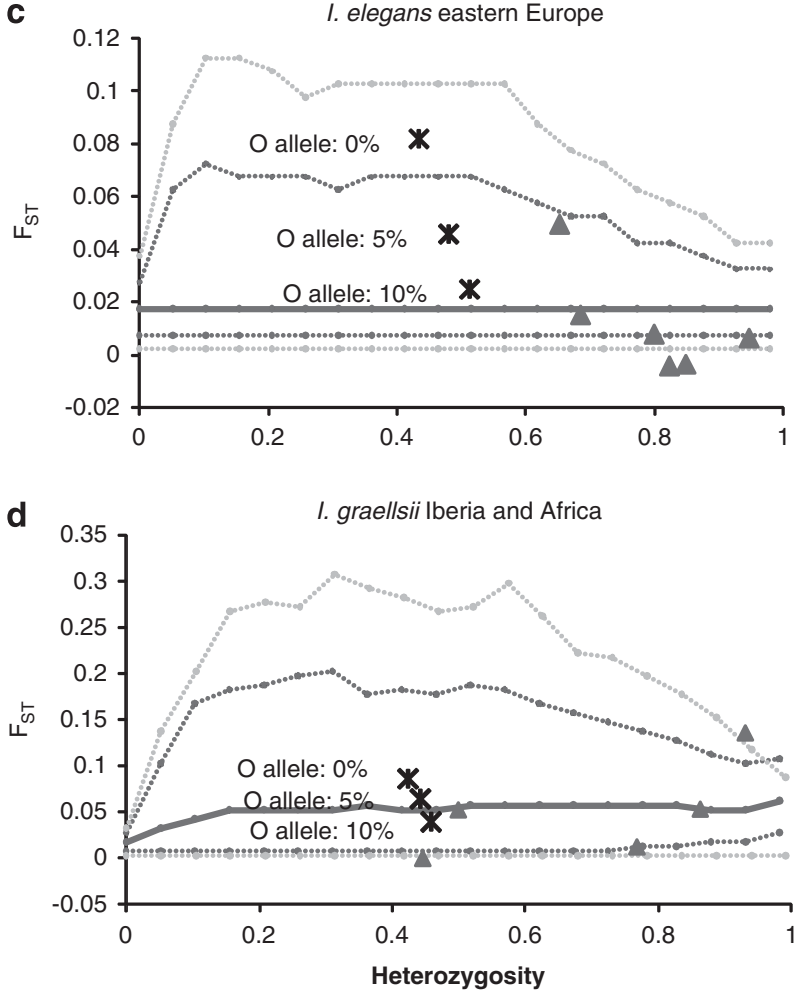

Figure 2 Summary of the results from the $F_{\mathrm{ST}}$-outlier analyses (using hierarchical island models implemented in Arlequin 3.5) showing the $F_{\mathrm{ST}}$ values of the colour locus and the microsatellite loci, and the generated null distribution of neutral $F_{\mathrm{ST}}$ values. Data are for all I. elegans populations (a), for Spanish I. elegans (b), eastern European I. elegans (c), and all $I$. graellsii populations (d). Colour locus $F_{\mathrm{ST}}$ values were calculated assuming (in those populations where no infuscans-obsoleta (I. elegans) or aurantiaca (I. graellsii) females were sampled) that (i) the $\mathrm{O}_{\text {allele }}$ was indeed absent (that is, had a frequency of $0 \%$ ), or (ii) the $\mathrm{O}_{\text {allele }}$ was present at low frequencies (5 and $10 \%$, respectively). A full color version of this figure is available at the Heredity journal online.

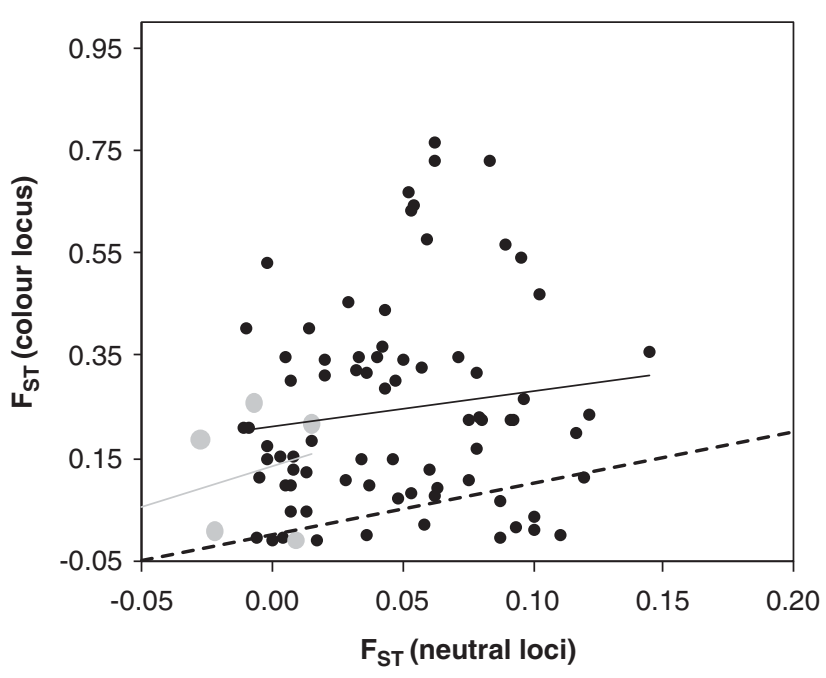

Figure 3 Correlation between colour-morph and neutral divergence between pairs of populations in I. elegans and in I. graellsii. In black, the values for I. elegans for the 13 studied populations (neutral data from six microsatellite loci), and in grey, the values for the four I. graellsii populations (neutral data from five microsatellite loci). The dotted line indicates the 1:1 relationship.

\section{Discussion}

Frequency of colour morphs in seven Ischnura species Recently, Fincke et al. (2005) revised the frequency of androchrome colour morphs in polymorphic odonates, and found that in only $17 \%$ of the 134 studied species, the androchrome morph was the most common morph for at least one of the populations examined. In line with this, we found that the androchrome morph dominated only in some populations of $I$. elegans, whereas in the other Ischnura species (I. graellsii, I. senegalensis, I. fluviatilis, I. damula and $I$. ramburii) the gynochrome morph dominated consistently. The same was true for one of the two $I$. denticollis populations (Table 2), as well as in I. genei and I. saharensis (RA Sánchez-Guillén, personal observation).

Interestingly, the colour-morph frequencies in the Spanish populations of I. elegans varied widely, even at a local scale, whereas similar frequencies were found among populations in eastern Europe (Ukraine and Poland). The androchrome morph dominated in some Spanish populations (maximum frequency 75\%), whereas the infuscans morph (maximum frequency 75\%) and the infuscans-obsoleta morph (maximum frequency 77\%) dominated in others. Similar patterns have been observed in previous studies of $I$. elegans at both regional and continental scales (Gosden, 2008; Hammers and Van Gossum, 2008; Sánchez-Guillén et al., 2005). It is particularly interesting that the degree of morph-frequency differentiation in $I$. elegans was most pronounced in the recently founded Spanish populations at the southern range limit of the species (Gosden, 2008; Sánchez-Guillén et al., 2005). As a mirror-image of this, population differentiation in morph frequencies was also substantial at the northern range limit in Sweden, which has been explained as a result of the combined action of genetic drift, non-equilibrium conditions, extinctionre-colonisation dynamics and harsh environmental conditions at the range limits that leads to strong divergent selection (Abbott et al., 2008; Gosden, 2008). In general, strong divergent selection in novel environments would 
be expected to operate at the edges of a species range, often in combination with small effective population sizes (Kirkpatrick and Barton, 1997; Eckert et al., 2008).

In contrast to the pattern observed in I. elegans, I. graellsii showed more conserved colour-morph frequencies between populations in Iberia and northern Africa. The gynochrome infuscans morph was always the most common morph (maximum frequency 90\%), although either the aurantiaca (gynochrome) or the androchrome morph was the least common one. A similar pattern was found for I. senegalensis, I. fluviatilis, I. damula and I. ramburii, wherein the gynochrome morph was always found to be the most predominant morph in the surveyed populations, and the proportion of colour morphs showed little variation among regions.

These results suggest that the frequencies of the colour morphs in the Ischnura species studied are usually similar between populations as well as species, and that the gynochrome morph is most often the predominant type. This stability of colour morphism frequencies indicates that some sort of balancing selection is likely to operate in these species (cf. Svensson et al., 2005; Abbott et al., 2008). An exception to this seems to occur in some regions of the distribution range of I. elegans, because our analyses detected substantial variation in colour-morph frequencies among populations, with the androchrome morph being in several instances the most frequent morph present. It would be interesting to investigate the colour-morph frequencies in other polymorphic species in the genus Ischnura, to test if I. elegans is the only Ischnura species where the gynochrome does not typically dominate.

Selection on the colour locus in I. elegans and I. graellsii The correlation between $F_{\mathrm{ST}}$ values at the neutral markers and the colour locus was very weak in I. elegans $\left(r^{2}=0.018\right)$, discarding that the morph-frequency variation between populations in this species is highly affected by genetic drift (cf. Runemark et al., 2010). The degree of differentiation between pairs of populations at the colour locus in I. elegans was in several cases considerably larger than at the neutral loci, suggesting that divergent selection can have important effects in shaping morph frequencies in I. elegans. Furthermore, the $F_{\mathrm{ST}}$-outlier analyses supported the importance of divergent selection on the colour morph in I. elegans (cf. Beaumont and Nichols, 1996; Excoffier et al., 2009). The $F_{\mathrm{ST}}$ value of the colour morph was a sharp outlier when all populations of $I$. elegans were analysed together (Spain and eastern Europe; Figure 2a), and also when only the Spanish populations were considered (Figure 2b). Thus, although the colour morph-frequency variation differs largely between I. elegans regions, our results suggest that the patterns of morph frequencies might partly be affected by divergent selection favouring certain morphs in local populations that differ in ecology and abiotic factors. Potentially important factors might be temperature and precipitation or other local microclimatic factors that are likely to affect the different colour morphs in contrasting ways (Bots et al., 2009). For instance, Gosden (2008) found a highly significant north-south cline in the frequency of the androchrome female morph, that became much more common at higher latitudes in Europe, such as in Sweden. This might indicate that the androchrome female morph is more cold-adapted or cold-tolerant than the other morphs. Furthermore, a similar cline in the female morph frequency has been observed in another Coenagrionid in Canada, Nehalennia irene. This species shows a high androchrome frequency in its western distribution, where it is the majority morph, but the frequency decreases eastwards and is in minority in the east (Van Gossum et al., 2007; Iserbyt et al., 2010). This cline in the androchrome frequency has been related to some underlying selective agents, but also with genetic drift during recolonisation (Iserbyt et al., 2010). Significant clines in adaptive traits are usually considered as classical signature of selection (Endler, 1997).

Under a scenario of divergent selection (and if the stabilising force of negative frequency-dependent selection is not strong enough, relative to the strength of divergent selection), dispersal between populations, or temporal variation in factors that affect which morph is locally favoured, could contribute to the maintenance of the colour-morph polymorphism in local populations. Even if we assume that the recessive $\mathrm{O}$ allele, that codes for the infuscans-obsoleta morph, is present at low frequencies in populations where the infuscans-obsoleta morph was not found, the colour locus was still detected as an $F_{\mathrm{ST}^{-}}$outlier when all populations of I. elegans were analysed together (Figure 2a), but it fell inside the expected neutral distribution in the eastern European populations (Figure 2c). These results suggest that the female colour polymorphism might in some regions (for example, eastern Europe) be partly affected by stochastic factors such as genetic drift, perhaps in combination with different types of selection (for example, negative frequency-dependent selection), whereas divergent selection might be the predominant force in other regions of Europe (for example, Spain). It is also worth highlighting that the Iberian populations of I. elegans have been relatively recently founded, as this species has only in the last few years expanded its distributional range south-westwards (Monetti et al., 2002; Sánchez-Guillén et al., 2005). As I. elegans might be in the process of expanding into new geographic areas that are characterised by novel selection pressures, it is perhaps not surprising that divergent selection might be particularly strong in Spain. More generally, selection in peripheral populations of a species range might a priori be expected to be strong, although its effects on the allele frequencies in local populations might be counteracted by gene flow from better-adapted populations at the centre of a species range (Kirkpatrick and Barton, 1997; Bridle and Vines, 2007).

Populations of I. graellsii showed a similar pattern to the I. elegans populations from eastern Europe, and the $F_{\mathrm{ST}}$ value of the colour locus did not deviate from the expected neutral distribution (Figure 2d). Thus, we found no signature of divergent or balancing selection operating on the morph frequencies among Iberian I. graellsii populations. Rather, the morph frequencies might have been partly influenced by genetic drift, as indicated by the weak positive (non-significant) correlation between genetic differentiation at the colour locus and the neutral loci $\left(r^{2}=0.27\right)$.

Field studies of selection have shown that selection often varies both spatially and temporally, and typically differ in magnitude, direction and/or form (Grant and Grant, 2002; Svensson and Sinervo, 2004; Abbott et al., 
2008; Gosden and Svensson, 2008). Thus, the possibility to detect balancing selection (for example, negative frequency-dependent selection) may depend on the geographical scale of the study. Andrés et al. (2000) and Abbott et al. (2008) suggested that balancing selection affected the colour-morph frequencies in Spanish I. graellsii and Swedish I. elegans, respectively (see also Gosden 2008). These results differ from the results concerning divergent selection in this study. Our study contained samples from a geographically extensive area (maximum distance between pair of populations $=960 \mathrm{~km}$ ) compared with the relatively small spatial scale that was explored in Andrés et al. (2000) (maximum distances $=50 \mathrm{~km}$ ) and Abbott et al. (2008) (maximum distances $=20 \mathrm{~km}$ ). At such small local scales, the balance between the stabilising force of negative frequency-dependent selection and divergent selection due to abiotic environmental heterogeneity is likely to be tipped in favour of the former. The reason for this is that these closely located populations are expected to be quite similar in ecological and abiotic environmental conditions. In contrast, at a larger geographic scale, as in our study, overall morph frequencies are more likely to be influenced by divergent selection due to environmental heterogeneity, even if the frequencies could be similar between closely located populations. Clearly, the spatial and temporal scale of sampling should be considered carefully in studies like the current one when aiming to obtain indirect inferences about selection.

To conclude, the examination of morph frequencies in different Ischnura spp. (Tables 1 and 2) has shown that gynochrome morphs are typically dominant, with the exception of $I$. elegans. The relatively stable morph frequencies across species suggest that balancing selection is likely to operate and maintain colour-morph frequencies in these species, and that the role of genetic drift is relatively minor, which has also been suggested in other studies (Svensson et al., 2005). The differentiation in colour-morph frequencies between Spanish I. elegans populations was significantly higher than that would be expected by genetic drift alone (Figure 2), which suggests an influence of divergent selection. In contrast, colourmorph frequencies in populations of I. elegans in eastern Europe and in I. graellsii populations varied much less geographically and did not differ from neutral expectations. That we found no evidence for strong stabilising selection within species could have been caused by the geographic scale of our sampling and the relatively low neutral population divergence in these damselflies. Low neutral population divergence is one of several factors that contribute to make the detection of stabilising selection much more difficult than the detection of divergent selection (Excoffier et al., 2009). Thus, our results do not refute negative frequency-dependent selection, because the statistical power to detect this was low using these kind of indirect inferences about selection (Excoffier et al., 2009).

In summary, the results of this study together with other recent studies on the population biology of the genus Ischnura (Andrés et al., 2000; Abbott et al., 2008; Gosden, 2008) suggest that both stochastic and deterministic factors affect population divergence in the colour locus of these polymorphic damselflies. The results of this study have clear implications for explaining the maintenance and frequency distribution of colour morphs in odonates, and suggest that a single hypothesis is not enough to understand the evolution of this phenomenon, not even within species.

\section{Conflict of interest}

The authors declare no conflict of interest.

\section{Acknowledgements}

We would like to thank two anonymous reviewers for helpful comments on earlier versions of this manuscript. We would like to thank for help with fieldwork Iñaki Mezquita, Tomás Latasa, Mario García-París, Bernat Garrigós, Pere Luque, Xoaquín Baixeras, Francisco Cano, Jean Pierre Boudot, Jürgen Ott, Cedrick Vanappelghem, Phillip Lambert and Phill Watts. This research was funded by the Spanish Ministry of Science and Innovation, grant CGL2008-02799 and CGL2008-03197-E. RSG is supported by a grant (Formación de Personal Investigador) from Spanish Ministry of Science and Innovation. $\mathrm{BH}$ and EIS are supported by grants from the Swedish Research Council, and MW by a Marie Curie Intra European fellowship. Permits to capture damselflies in Spain were issued by each Regional Government to RSG.

\section{References}

Abbott J, Bensch S, Gosden T, Svensson EI (2008). Patterns of differentiation in a colour polymorphism and in neutral markers reveal rapid genetic changes in natural damselfly populations. Mol Ecol 17: 1597-1604.

Andrés JA, Sánchez-Guillén RA, Cordero-Rivera A (2000). Molecular evidence for selection on female colour polymorphism in the damselfly Ischnura graellsii. Evolution 54: 2156-2161.

Andrés JA, Sánchez-Guillén RA, Cordero-Rivera A (2002). Evolution of female colour polymorphism in damselflies: testing the hypotheses. Anim Behav 63: 677-685.

Beaumont MA, Nichols RA (1996). Evaluating loci for use in the genetic analysis of population structure. 263: 1619-1626.

Bots J, De Bruyn L, Van Dongen S, ssssss R, Van Gossum H (2009). Female polymorphism, condition differences, and variation in male harassment and ambient temperature 97: 545-554.

Bridle JL, Vines TH (2007). Limits to evolution at range margins: when and why does adaptation fail? TREE 22: 140-147.

Carchini G, Cobolli M, De Mathaesis E, Utzeri C (1994). A study on genetic differentiation in the Mediterranean Ischnura Charpentier (Zygoptera: Coenagrionidae). Adv Odonatol 6: 11-20.

Cordero A (1990). The inheritance of female polymorphism in the damselfly Ischnura graellsii (Rambur) (Odonata: Coenagrionidae). Heredity 64: 346

Cordero A (1992). Density-dependent mating success and colour polymorphism in females of the damselfly Ischnura graellsii. J Anim Ecol 61: 769-780.

Cordero A, Andrés JA (1996). Colour polymorphism in Odonates: females that mimic males? J Br Dragonfly Soc 12: $50-60$.

Cordero-Rivera A, Sánchez-Guillén RA (2007). Male-like females of a damselfly are not preferred by males even if they are the majority morph. Anim Behav 74: 247-252.

Córdoba-Aguilar A (1993). Population structure in Ischnura denticollis (Burmeister) (Zygoptera: Coenagrionidae). Odonatologica 22: 455-464.

Dijkstra B, Lewington R (2006). Field Guide to the Dragonflies of Britain and Europe. British Wildlife Publishing: Dorset, UK.

Eckert CG, Samis KE, Ougheed CL (2008). Genetic variation across species' geographical ranges: the central-marginal hypothesis and beyond. Mol Ecol 17: 1170-1188. 
Endler JA (1997). Geographic Variation, Speciation and Clines. Princeton University Press: Princeton, NJ.

Excoffier L, Hofer T, Foll M (2009). Detecting loci under selection in a hierarchically structured population. Heredity 103: 285-298.

Fincke OM (2004). Polymorphic signals of harassed female odonates and the males that learn them support a novel frequency-dependent model. Anim Behav 67: 833-845.

Fincke OM, Jödicke R, Paulson D, Schultz T (2005). The evolution and frequency of female colour morphs in Holartic Odonata: why are male-like females typically the minority? Int J Odonatol 8: 183-202.

Fisher R (1958). The Genetical Theory of Natural Selection. Dover: New York.

Gillespie RM, Oxford GS (1998). Selection on the colour polymorphism in Hawaiian happy-faces spiders: evidence from genetic structure and temporal fluctuations. Evolution 52: 775-783.

Gosden T (2008). The Preservation of Favoured Morphs in the Struggle Between Sexes. Lund University.

Gosden T, Svensson EI (2008). Spatial and temporal dynamics in a geographic sexual selection mosaic. Evolution 62: 845-856.

Gosden T, Svensson EI (2009). Density-dependent male harassment, female resistance, and male mimicry. Am Nat 173: 709-721.

Goudet J (1995). FSTAT version 1.2. A computer program to calculate F-statistics. J Hered 6: 485-486.

Goudet J (2001). FSTAT, a program to estimate and test gene diversities and fixation indices, version 2.9.3. Available from http:/ / www.unil.ch/popgen/softwares/fstat.htm.

Grant PR, Grant BR (2002). Unpredictable evolution in a 30-year study of Darwin's Finches. Science 296: 707-711.

Gray SM, McKinnon JS (2007). Linking colour polymorphism maintenance and speciation. Trends Ecol Evol 22: 71-79.

Hammers M, Van Gossum H (2008). Variation in female morph frequencies and mating frequencies: random, frequencydependent harassment or male mimicry? Anim Behav $\mathbf{7 6}$ 1403-1410.

Hedrick PW (1985). Genetics of Populations. Jones and Barlett Publishers: Boston, MA.

Hilton DFJ (1987). A terminology for females with colour patterns that mimic males. Entomol News 98: 221-223.

Hinnekint BON (1987). Population dynamics of Ischnura elegans (Vander Linden) (Insecta: Odonata) with special reference to morphological colour changes, female polymorphism, multiannual cycles and their influence on behaviour. Hydrobiologia 146: 3-31.

Hinnekint BON, Dumont HJ (1989). Multi-annual cycles in populations of Ischnura elegans induced by crowding and mediated by sexual aggression (Odonata: Coenagrionidae). Entomol Gen 14: 161-166.

Hoffman E, Schueler F, Jones A, Blouins M (2006). An analysis of selection on a colour polymorphism in the northern leopard frog. Mol Ecol 15: 2627-2641.

Iserbyt A, Bots J, Van Gossum H, Jordaens K (2010). Did historical events shape current geographic variation in morph frequencies of a polymorphic damselfly? J Zool 282: 256-265.

Johnson C (1964). The inheritance of female dimorphism in the damselfly Ischnura damula. Genetics 49: 513-519.

Kay EH, Londsdorf EV, Pruett-Jones S (2007). Null models for population variation in morph frequencies in polymorphic damselflies. Anim Behav 74: e1-e8.

Kirkpatrick M, Barton NH (1997). The strength of indirect selection on female mating preferences. Proc Natl Acad Sci 94: 1282-1286.

Mckee D, Harvey IF, Thompson DJ, Sherratt TN (2005). Frequency of female colour morphs in populations of four coenagrionid damselflies (Zygoptera: Coenagrionidae). Odonatologica 34: 37-49.

Miller MN, Fincke OM (1999). Cues for mate recognition and the effect of prior experience on mate recognition in Enallagma damselflies. J Insect Behav 12: 801-814.
Monetti L, Sánchez-Guillén RA, Cordero-Rivera A (2002). Hybridization between Ischnura graellsii (Vander Linder) and I. elegans (Rambur) (Odonata: Coenagrionidae): are they different species? Biol J Linn 76: 225-235.

Nevo E (1997). 'Evolution Canyon': a natural microscale model of evolution in action. Annu Rev Plant Genet 52: 231-243.

Orr HA (1998). Testing natural selection vs. genetic drift in phenotypic evolution using quantitative trait locus data. Genetics 149: 2099-2104.

Oxford GS (2005). Genetic drift within a protected polymorphism: enigmatic variation in colour-morph frequencies in the candy-stripe spider, Enoplognatha ovata. Evolution 59: 2170-2184.

Pritchard JK, Stephens M, Donnelly P (2000). Inference of population structure using multilocus genotype data. Genetics 155: 945-959.

Robertson HM (1985). Female dimorphism and mating behaviour in a damselfly, Ischnura ramburii: females mimicking males. Anim Behav 33: 805-809.

Runemark A, Hansson B, Pafilis P, Valakos ED, Svensson EI (2010). Island biology and morphological divergence of the Skyros wall lizard Podarcis gaigeae: a combined role for local selection and genetic drift on color morph frequency divergence? BMC Evol Biol 10: 269.

Sambrook J, Fritsch EF, Maniatis T (1989). Molecular Cloning: A Laboratory Manual. Cold Spring Harbor laboratory Press: Cold Spring Harbor, New York.

Sánchez-Guillén RA, Van Gossum H, Cordero-Rivera A (2005). Hybridization and the inheritance of female colour polymorphism in two Ischnurid damselflies (Odonata: Coenagrionidae). Biol J Linn Soc 85: 471-481.

Sánchez-Guillén RA, Wellenreuther M, Cordero A, Hansson B. Admixture analysis reveals introgression in Ischnura damselflies in a recently established sympatric region (under review).

Sherratt TN (2001). The evolution of female-limited polymorphisms in damselflies: a signal detection model. Ecol Lett 4: 22-29.

Sirot LK, Brockmann HJ, Marnis C, Muschett G (2003). Maintenance of a female-limited polymorphism in Ischnura ramburii (Zygoptera: Coenagrionidae). Anim Behav 66: 763-775.

Svensson EI, Abbott J, Gosden T, Coreau A (2009). Female polymorphisms, sexual conflict and limits to speciation processes in animals. Evol Ecol 23: 93-108.

Svensson EI, Abbott J, Härdling R (2005). Female polymorphism, frequency dependence, and rapid evolutionary dynamics in natural population. Am Nat 165: 567-576.

Svensson EI, Sinervo B (2004). Spatial scale and temporal component of selection in side-blotched lizards. Am Nat 163: 726-734.

Takahashi Y, Watanable M (2009). Diurnal changes and frequency dependence in male mating preference for female morphs in the damselfly, Ischnura senegalensis (Rambur) (Odonata: Coenagrionidae). Entomol Sci 12: 219-226.

Van Gossum H, Beirinckx K, Forbes M, Sherratt T (2007). Do current hypotheses explain continental and seasonal variation in female morph frequencies of the damselfly, Nehalennia irene? Biol J Linn Soc 90: 501-508.

Weir BS, Cockerham (1984). Estimating F-statistics for the analysis of population structure. Evolution 38: 1358-1370.

Wellenreuther M, Sánchez-Guillén R A, Cordero-Rivera A, Hansson B 2010. Development of 12 polymorphic microsatellite loci in Ischnura elegans (Odonata: Coenagrionidae). Molecular Ecology Resources; MER database ID 43577. http://tomato.biol.trinity.edu/locus_details.php?id $=43577$.

Wong A, Smith ML, Forbes MR (2003). Differentiation between subpopulations of a polychromatic damselfly with respect to morph frequencies, but not neutral genetic markers. Mol Ecol 12: 3505-3513.

Wright S (1931). Evolution in Mendelian populations. Genetics 16: 97-159.

Wright S (1956). Modes of selection. Am Nat 90: 5-24. 